\title{
Bronchiole Epithelium
}

National Cancer Institute

\section{Source}

National Cancer Institute. Bronchiole Epithelium. NCI Thesaurus. Code C48942.

The epithelium of the bronchioles of the lung, which consists of cuboidal cells. 